\title{
ANALYSIS OF PROFIT FUNCTION AND RETURNS TO SCALE OF RICE FARMING IN TIDAL AND FRESHWATER SWAMPLANDS IN SOUTH KALIMANTAN
}

\author{
Rifiana, Kamiliah Wilda, Yudi Ferrianta \\ Agricultural Economics Department, Agricultural Faculty, Lambung Mangkurat University \\ Banjarbaru, South Kalimantan, Indonesia \\ Email : rifiana79@yahoo.com
}

\begin{abstract}
The purpose of this study was to estimate the production and profit function by farmers and to analyze the relative economic efficiency of rice farming in two typologies of wetland, tidal swampland and freshwater swampland. The analysis showed that the production facilities in the study area were very influential on the rice farming profit, so an increase in the high price of production facility would lead to a decrease in profit, which in turn would lower the level of farmers' welfare. Under optimal conditions where maximum profit was reached, the effects of variable input prices and the input number remained significant except for the value of the equipment used. Based on the value of the coefficient function of fertilizer demand, pesticide and labor were inelastic towards the price while the seed input was elastic. Rice farming in the study area had decreasing returns to scale. It indicated that the increase in inputs was higher than the increase in returns.
\end{abstract}

Keywords: profit function, rice farming, returns to scale

\section{INTRODUCTION}

Development focuses on the growth of sectors that can contribute to the high economic growth. The objectives of development basically cover several aspects, namely economic growth, equitable distribution of income and sustainability of the resource and environment. The success of development requires the cooperation and support from various parties, and demands the roles of every sector. Considering the potential, agriculture is the most dominant and has the potential to be developed. The agricultural sector with all its potential and significant contribution has the role to the achievement of economic development if it is properly managed.

The increase in food security is one of the national development objectives. In terms of production, the increase in food security is sought through the increase in rice production which has the greatest contribution to the consumption of calories.

In South Kalimantan, the lands that have large areas and are potentially developed are freshwater swamplands. In order to make the development of the lands for rice farming in line with the carrying capacity for the sustainability of cultivation, it is necessary to pay attention to the development that takes into account the economic and ecological interests. The development of swamp lands generally must meet three conditions, namely technically feasible and acceptable to society, economically feasible and profitable and not harmful to the environment. Therefore, it is interesting to study the efficient allocation of the input use and to analyze the profit of rice farming in the two typologies of wetlands in order to provide suggestion on the policy of wetland utilization as the alternative agricultural lands in South Kalimantan.

The purpose of this study was to estimate the production function and profit function by farmers and to analyze the relative economic efficiency in rice farming in two typologies of wetlands, freshswater wamp and tidal lands.

\section{MATERIALS AND METHODS}

The research was carried out at two wetland agroecosystem in South Kalimantan, namely tidal swampland and freshwater swamplands. Banjar regency was chosen to represent the agroecosystem of tidal swampland and Hulu Sungai Utara (HSU) Regency the freshwater swampland.

Primary and secondary data were used in this research. Primary data was collected through a structured interview guided with questionnaires to farmers who managed their rice farming in tidal and freshwater swamplands. The farmers selected for the study were the ones who had experience in managing rice farming in tidal 
and freshwater swamplands of at least four planting seasons. The secondary data were taken from various institutions (Statistics of South Kalimantan; Department of Agriculture; Food Security Agency and other agencies) that were considered relevant and their data were capable of supporting the research activities.

The total number of selected villages in this study was 4 villages. From each village, the sample farmers were randomly determined by proportionate random sampling. The overall number of farmers for the primary data source was 72 respondents consisting of 36 farmers as the samples for tidal swampland; and 36 farmers as the samples for freshwater swampland.

The analysis model used to estimate the factors influencing the rate of profit, allocation of production factor use, returns to scale and level of relative economic efficiency was a profit function model of Cobb-Douglas which was derived from the production function model of Cobb-Douglas. The use of primary data (cross section) meant the longterm model that indicated the production process could be assumed a long-term context. Furthermore, to estimate the profit function, returns to scale and efficiency levels, the program of SAS 9 was applied.

\section{Model of Cobb-DouglasProfit Function}

The Cobb-Douglas Profit Function was used to determine the relationship between input and output, and to measure the impact of various changes in the input prices on the production. The Cobb-Douglas Profit Function method has been famous since it was introduced by Lau and Yotopoulos in 1976, and become a concept that could be operated to test the relative efficiency in agriculture.

The latest development is lowering the Cobb-Douglas Profit Function with the technique of "Output Unit Price" or UOP of Cobb-Douglas Profit Function, which is a function that involves the production price and the production which has been normalized at a fixed price, called "Normalized Profit Function".

One of the benefits of the use of this function is that researchers can at once measure the levels of efficiency at different levels or traits. Four variable inputs and 3 fixed inputs were inserted into the Cobb-Douglas profit function. The shape of the Cobb-Douglas production function is as follow:

$$
\mathrm{Y}=\mathrm{A} \mathrm{X}_{1}{ }^{\mathrm{xi}} \mathrm{X}_{\mathrm{Z}}{ }^{\mathrm{a} 2 m} \mathrm{X}_{3}{ }^{\mathrm{a} 3} \mathrm{X}_{4}{ }^{a 4} \mathrm{Z}_{1}{ }^{\beta 1} \mathrm{Z}_{2}{ }^{\beta 2}
$$

Note:

$$
\begin{aligned}
& \mathrm{Y}_{1}=\text { rice production } \\
& \mathrm{X}_{1}=\text { labor } \\
& \mathrm{X}_{2}=\text { number of seeds } \\
& \mathrm{X}_{3}=\text { fertilizer } \\
& \mathrm{X}_{4}=\text { pesticide } \\
& \mathrm{Z}_{1}=\text { land area }
\end{aligned}
$$$$
\ln \pi^{*}=A^{*} \sum w i^{a i^{*}} \sum Z^{\beta j^{*}}
$$

$Z_{2}=$ miscellaneous cost

$\alpha^{1}=$ input coefficient of variable $i$

$\beta \mathrm{j}=$ fixed input coefficient of variable $\mathrm{j}$ According to Yotopoulos and Lau (1971), from the equation (2.1) it could be derived the profit function of UOP (Unit Output Price) as follows:

In the form of natural logarithms, the equation (2.2) could be written as follows:

$$
\begin{aligned}
& \operatorname{In} \pi^{*}=\ln A^{*} \sum \alpha i^{*} \operatorname{lnwi} i^{*} \sum \beta j^{*} \ln Z j \\
& \ln \pi^{*}=\ln A^{*}+\alpha_{1}{ }^{*} \ln w_{1}+\alpha_{2}{ }^{*} \operatorname{lnw}_{2}+\alpha_{3}{ }^{*} \ln w_{3}+\alpha_{4}{ }^{*} \ln w_{4}+\beta_{1}{ }^{*} \ln Z_{1}+\beta_{2}{ }^{*} \ln z_{2}+e 0
\end{aligned}
$$

Note:

$\pi^{*} \quad=$ short-term profit that had been normalized by the price of grain

$\mathrm{A}^{*}=$ intercept

$\mathrm{W} 1^{*}=$ labor cost which had been normalized by the price of grain

$\mathrm{W} 2{ }^{*}=$ seed price which had been normalized by the price of grain

$\mathrm{W}^{*}{ }^{*}=$ fertilizer price which had been normalized by the price of grain
W4 * = pesticide cost which had been normalized by the price of grain

$\mathrm{Z1}=$ fixed input of land area

$Z 2$ = fixed input of miscellaneous cost

$\alpha^{*}=$ parameter of expected variable input, $i=1, \ldots \ldots \ldots \ldots \ldots . .5$

$\beta \mathrm{j}^{*}=$ parameter of expected fixed output, $\mathrm{j}=1,2$

$\mathrm{e} 0=$ error factor (standard error)

The demand function of variable input

(factor share) as the contribution of a variable 
input to profits could be derived from the Cobb-Douglas function profit (Yotopoulos and Nugent, 1976 and Sukartawi, 1990)

$$
\begin{aligned}
& -W_{i} X_{i} / \pi_{a}=\alpha_{i}{ }^{* \prime}+e i ; i=1,2,3,4 . \\
& X i=-\alpha_{i}^{* \prime} \pi_{a} / W_{i}^{*}
\end{aligned}
$$

which mathematically could be formulated into:

\section{Note:}

$\mathrm{Wi}^{*}=$ price of variable input normalized by the price of rice

$\Pi_{a}=$ short-term UOP profit

$\alpha_{i}{ }^{* \prime}=$ parameter of variable input of factor share

$X_{1}=$ the number of value of labor and cost inputs in rupiah

$$
\begin{aligned}
& X_{2}=\begin{array}{l}
\text { the number of SP-36 fertilizer input } \\
\text { values in rupiah }
\end{array} \\
& X_{3}=\text { the number of Urea fertilizer input } \\
& \text { values in rupiah } \\
& X_{4}=\text { the number of pesticide input values } \\
& \text { in } \\
& \text { ei } \begin{array}{l}
\text { error factor } \\
\text { And the output supply function in }
\end{array}
\end{aligned}
$$
equation (3.6) can be lowered as follows:

$$
\mathrm{Y}_{\mathrm{s}}{ }^{*}=\left(1-\sum \alpha_{\mathrm{i}}{ }^{* \prime \prime}\right) \Pi_{\mathrm{a}} \text {. }
$$

Equation (3.7) in the natural logarithma has the formulation as follows:

$$
\begin{aligned}
& \ln Y_{s}{ }^{*}=\ln \left(1-\sum \alpha_{i}{ }^{* \prime}\right)+\ln \pi_{a} \\
& \ln Y s^{*}=\ln \left(1-\sum \alpha_{i}{ }^{* \prime}\right)+\ln A^{*}+\sum \alpha_{i}^{*} \ln w i^{*} \sum \beta_{i}^{*} \ln Z j \sum \alpha_{i}{ }^{*} \sum \beta j^{*} \ln Z j \ldots
\end{aligned}
$$

As a consideration in resolving the profit function of UOP (Unit Output Price), the simultaneous way is used to achieve stochastic specification, where the analysis model has $\mathrm{ai}^{*}$ which appeared in all the equations. If the case used the OLS, there would be inefficiency and it was feared that there was the emergence of a correlation among the errors of each equation. Therefore, the prediction of UOP profit function would be solved using three models.
The use of these three models would show a correlation among the errors of each equation so that an efficient model could be obtained.

\section{Model I: Model OLS as the comparison}

Profit function equation of the factor share function on the farming in the study area consisted of a single profit function and four factor share functions, i.e.

$$
\begin{aligned}
& \ln \pi^{*}=\ln A^{*}+\alpha_{1}{ }^{*} \ln w 1^{*}+\alpha_{2}{ }^{*} \ln w 2^{*}+\alpha_{3}{ }^{*} \ln w 3^{*}+\alpha 4^{*} \ln w 4^{*}+\beta i^{*} \ln z \mid+\left(\beta 2^{*} \ln z 2+\beta 3^{*} \ln z 3+\operatorname{eo~(2.10)~}\right. \\
& \ln X_{1}=\ln \left(-\left.\alpha\right|^{* \prime \prime}\right)+c x 2^{*} \ln w 2^{*}+\alpha_{3}{ }^{*} \ln w 3^{*}+\alpha_{4}{ }^{*} \ln w 4^{*}+\beta_{i}{ }^{*} \ln z \mid+\beta_{2}{ }^{*} \ln Z 2+\beta 3^{*} \ln Z 3+\text { eo (2.11) } \\
& \ln X_{2}=\ln \left(-\alpha 2^{* \prime}\right)+c x 2^{*} \ln w 2^{*}+\alpha 3^{*} \ln w 3^{*}+\alpha 4^{*} \ln w 4^{*}+\beta i^{*} \ln z \mid+\beta 2^{*} \ln z 2+\beta 3^{*} \ln Z 3+\text { eo (2.12) } \\
& \ln X_{3}=\ln \left(-\alpha 3^{* \prime}\right)+c x 2^{*} \ln w 2^{*}+\alpha 3^{*} \ln w 3^{*}+\alpha 4^{*} \ln w 4^{*}+\beta i^{*} \ln z \mid+\beta 2^{*} \ln z 2+\beta 3^{*} \ln Z 3+\text { eo (2.13) } \\
& \ln X_{4}=\ln \left(-\alpha^{*}\right)+c x 2^{*} \ln w 2^{*}+\alpha 3^{*} \ln w 3^{*}+\alpha 4^{*} \ln w 4^{*}+\beta i^{*} \ln z \mid+\beta 2^{*} \ln z 2+\beta 3^{*} \ln Z 3+\text { eo (2.14) }
\end{aligned}
$$

The above five equations were single equation which was processed partially or individually.

Model II: Zellner's model Method Seemingly Unrelated Regression without similarity restriction $\alpha^{*}=\alpha^{* \prime}$, which was a simultaneous equation using five equations in model 1 that were processed synchronously or simultaneously.
Model III: Zellner's Method of Seemingly Unrelated Regression model with restriction similarity $\alpha^{*}=\alpha^{*}$, which was the simultaneous equation and processed simultaneously. Five equations as Model I restricted were $\alpha^{*}=\alpha^{* \prime}$, so it became as follows: 


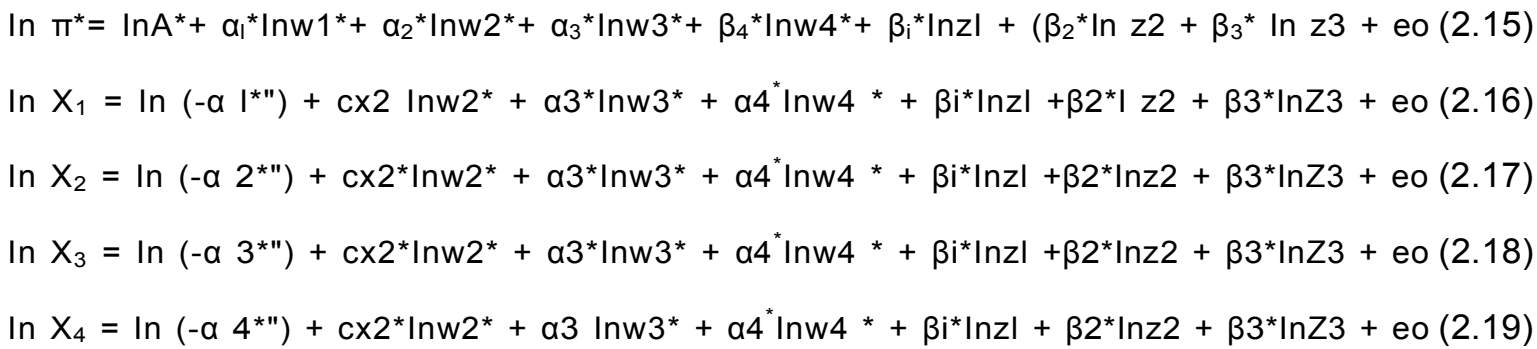

Restrict In $w 1^{*}=\ln \left(\alpha_{1}{ }^{*}\right)$

Restrict In $w 2^{*}=\ln \left(\alpha_{2}{ }^{*}\right)$

Restrict In $w 3^{*}=\ln \left(\alpha_{3}^{* "}\right)$

Restrict In $w 4^{*}=\ln \left(\alpha_{4}{ }^{*}\right)$

In the two groups, according to the different typologies of arable lands, were tidal swampland and freshwater swampland, the model used was by incorporating the dummy variables in the profit function of model I, II, III mentioned above. Dummy variable for tidal swampland $=0$ and freshwater swampland $=$ $I$, and thus the equation of Cobb-Douglas function profit of rice farming could be written as follows:

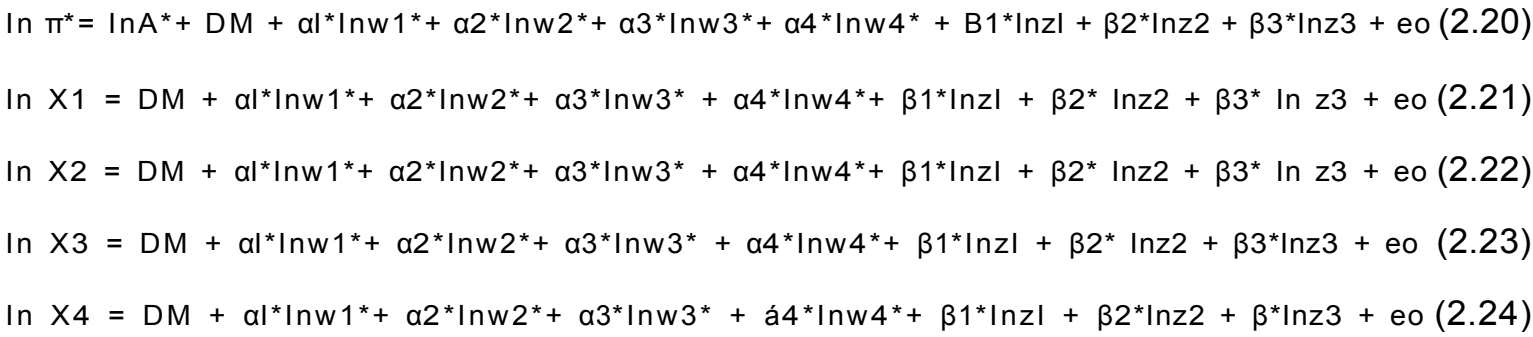

Model I and Model II were actual profit functions, while Model III was the profit function with the condition of achieved short-run maximum profits.

\section{Maximum Profit Testing}

The testing for the achievement of short-term maximum profit was done by comparing parameters of each changer (variable) on the production function $(\beta)$ with the parameter of each demand function of variable inputs $(\beta 1)$. Short-term maximum profit would be achieved if $\beta=\beta^{1}$ for all variables. Hence, the achievement form of short-run maximum profit was $\mathrm{Ho}: \beta \mathrm{i}=\beta \mathrm{i}^{1}$ $(i=1,2,3,4)$.

If there was one of Ho rejected, rice farming could not achieve short-run maximum profit.

\section{Returns to Scale Testing}

The testing of returns to scale was done on the value of $\mathrm{k}$ or $\sum \beta^{*} j$. If $\sum \beta^{*} j=1$, there was a constant returns to scale (CRS). The increasing returns to scale (IRS) happened when $\sum \beta^{*} j>1$, and the decreasing returns to scale (DRS) occurred when $\sum \beta^{*} j<1$. Thus, the returns to scale testing could be formulated as follows:

Ho: $\sum \beta^{*} j=1$ (CRS)

$\mathrm{Ha}: \sum \beta^{*} j \neq 1$ (IRS/DRS)

The test used was F-Test:

$F$ count $<F$ table, then Ho was accepted

$F$ count $>F$ table, then Ho was rejected

\section{RESULTS AND DISCUSSION}

\section{Estimation of profit function and input demand function}

To estimate the parameter, the equation of UOP (Unit Output Price) profit function and share factor function were used. Estimation was conducted based on the SUR (Seemingly Unrelated Regression) method which was found by Zellner (1962). The data in this study were processed using a computer with SAS 9.1 program. In this case, there was a profit function and four (4) equations of factor share function were estimated simultaneously. The dependent variable in the profit function was the normalized farming profit $\left({ }^{*}\right)$, and the 
independent variables included the variable input prices and fixed inputs.

Variable inputs used as the independent variables included the normalized average wage per worker $\left(\mathrm{W} 1^{*}\right)$, the normalized seed price $\left(\mathrm{W} 2^{*}\right)$, the normalized fertilizer price $\left(\mathrm{W}^{*}\right)$, the normalized pesticide cost $\left(\mathrm{W} 4^{*}\right)$. While the fixed inputs which were applicable as the independent variables included land area (Z1), depreciation (Z2) and labor outpouring (Z4) and DM showing the location of dummy land / land typology in one growing season. The four (4) equations of factor share mentioned above were the value of labor force (X1), the value of seed (X2), the value of fertilizers (X3), and the value of pesticides (X4).

The estimation of parameters of UOP profit function and factor share function in this study was presented in three models, namely Model 1 using a single equation of OLS (Ordinary Least Square), Model II using a simultaneous equation of SUR (Seemingly Unrelated Regression) Zellner without similarity restriction $\alpha^{*}=\alpha^{*}$ (indicating there was actual short-run profit) and Model III using a simultaneous equation of Zellner method with restriction $\alpha^{*}=\alpha^{* \prime}$ (indicating there was maximum short-run profit).

From the profit function equation, the input demand function and also output offer function could be derived at the same time.
In addition, the level of economic of scale could also be derived from the profit equation. Analysis of this profit function estimation used Unit Output Price of Cobb Douglas Profit Function, which is a function or equation that involves the production factor prices and production values normalized by the price of rice. This method also bases itself on the assumption that the farmers or entrepreneurs have maximized profits.

\section{Effect of production factor price on profit level}

The completion of profit function was performed with the three models; first, with OLS (Model I) which was used as a comparison to the other models, where each equation (profit function and demand function) was resolved on their own. The second model was with the method of seemingly Unrelated Regression (SUR) where all equations were solved simultaneously without similarity restriction $\alpha_{j}^{*}$ $\neq \alpha_{i}$ that was the condition of optimum input allocation or the achievement of maximum profit where $\alpha_{j_{*}}^{*}$ was the profit function parameter and $\alpha_{j}$. was the demand function parameter. The third model was with the method of seemingly Unrelated Regression (SUR) with restriction $\alpha_{j}^{*}=\alpha_{i}^{*}$. The analysis results of the three models were presented in Table 1.

Table 1. Estimation of rice farming profit function on swamp and tidal lands in South Kalimantan.

\begin{tabular}{lcccccc}
\hline \multirow{2}{*}{ Variable } & \multicolumn{2}{c}{$\begin{array}{c}\text { Model I } \\
\text { (OLS) }\end{array}$} & \multicolumn{3}{c}{$\begin{array}{c}\text { Model II (SUR) } \\
\alpha_{i}^{*} \alpha_{j}^{*} \neq \alpha_{i}^{*}\end{array}$} & \multicolumn{2}{c}{$\begin{array}{c}\text { Model III (SUR) } \\
\alpha_{i}^{*}=\alpha_{i}^{*}\end{array}$} \\
\cline { 2 - 7 } & $\begin{array}{c}\text { Parameter } \\
\text { Estimate }\end{array}$ & $\operatorname{Pr}>|\mathrm{t}|$ & $\begin{array}{c}\text { Parameter } \\
\text { Estimate }\end{array}$ & $\operatorname{Pr}>|\mathrm{t}|$ & $\begin{array}{c}\text { Parameter } \\
\text { Estimate }\end{array}$ & $\operatorname{Pr}>|\mathrm{t}|$ \\
\hline Intercept & 9.341583 & $<.0001$ & 9.533575 & $<.0001$ & 9.497539 & $<.0001$ \\
seed price & -0.52325 & 0.1653 & -0.79498 & 0.0311 & -1.31486 & $<.0001$ \\
fertilizer price & -1.10276 & 0.0033 & -1.18153 & 0.0014 & -0.83254 & 0.0136 \\
pesticide price & -0.81849 & $<.0001$ & -0.86526 & $<.0001$ & -0.70904 & $<.0001$ \\
labor cost & -0.8459 & 0.0236 & -0.82907 & 0.0219 & -0.93891 & 0.0026 \\
land area & 0.47296 & $<.0001$ & 0.399009 & $<.0001$ & 0.424655 & $<.0001$ \\
decrease & -0.07406 & 0.4312 & -0.07332 & 0.42 & -0.06638 & 0.46 \\
Outpouring TK & 0.26368 & 0.0034 & 0.225956 & 0.0089 & 0.278995 & 0.0011 \\
DM & 0.383838 & 0.0389 & 0.484013 & 0.0077 & 0.727547 & $<.0001$ \\
$\mathrm{R}^{2}$ & 0.83314 & & 0.9247 & & 0.9485 & \\
F count & 39.32 & & 17.07 & & 17.8 & \\
\hline
\end{tabular}

Source: Primary data processing (2016).

The estimation results of the three models, each of which had the value of $F$ count greater than the $\mathrm{F}$ table with $a$ significant level at $99 \%$ confidence level indicating that the specifications of the explained variables and explanatory 
variables included in the models were already considered accurate and reliable. From those $F$ values, it could also be concluded that all the independent variables (inputs) which were included in the model jointly affected the dependent variable (profit). The coefficient of determination $\left(R^{2}\right)$, each of which was greater $80 \%$, indicated that the three models were able to explain the total diversity of the dependent variable (profit) with a high proportion or percentage and the rest was caused by other factors outside the models built.

Estimation of the profit function of model I (OLS) indicated that the value of $F$ count was very significant (39.23) and the coefficient of determination $\left(R^{2}\right)$ was $83.33 \%$. The determination coefficient of $83.33 \%$ meant that the profit function models (independent variables) were able to explain approximately $83.33 \%$ of the diversity of the total profit quantity (UOP), while the rest of $16.672 \%$ was explained by other factors (which were not contained in the model). When it was compared with the model II which also had a significant value of $F$ count (17.07) with the determination coefficient greater than the model I $(92.25 \%)$. it indicated that the use of the model II would give the more reliable estimation.

By considering the purpose of model selection to test the null hypothesis based on the estimated parameters which were not biased, in this case the criteria of standard errors, the estimation in model II (SUR) looked better than that in model 1 (OLS). The values of standard errors in model II for all of the calculated parameters were smaller than those in model I, thus giving more significance level. This fact gave an indication that the estimation conducted simultaneously on two different equations using the SUR method gave better results than the other methods, so in further analysis of the discussion was based on the results of the model II (method SUR).

The seed price variable that had been normalized turned out to have coefficients that were negative on all models, so there was a negative relationship between the seed price and the profit rate. In the model II, coefficient value of the seed price was 0.7949 and significant at the confidence level of $99 \%$, where any increase in seed price by $10 \%$ caused a decline in profit by $7.95 \%$.

The cost variable of fertilizer that had been normalized also had a negative coefficient on all models, so there was a negative relationship between the seed price and the profit level. The fertilizer price coefficient was 1.181 and significant at the confidence level of $99 \%$ in model II; any increase in fertilizer price by $10 \%$ caused a decline in profit by $11.81 \%$.

The coefficient values of pesticide price and labor cost had a negative correlation with the profit level. The variable of pesticide price that had been normalized also had a coefficient that was negative in all models, so there was a negative relationship between the seed price and the profit level. The fertilizer price coefficient was - 0.8653 and significant at the confidence level of $99 \%$ in model II; any increase in fertilizer price by $10 \%$ caused a decline in profits by $8.651 \%$. The labor cost variable also had a coefficient - 0.8291 and was significant at the confidence level of $99 \%$ in model II, where any increase in fertilizer price by $10 \%$ caused a decline in profit by $8.29 \%$.

The equipment cost with a $p$-value of 0.42 at the confidence level of $90 \%$ did not significantly affect profits because the contribution of farming equipment cost was generally low while the arable land area significantly affected the confidence level of $99 \%$ ( $p$-value < 0.0001). It was because the land area which was getting wider would increase the rice production, and thus the total income of farmers would become greater.

The parameter of labor outpouring input was positive indicating that the greater labor input was poured out, the greater the profit was. The value of labor parameter significantly influenced the confidence level of $99 \%$ ( $p$-value $<0.0089$ ).

In optimal condition (Model III) where the maximum profit was reached, the effects of variable input prices and the number of fixed inputs were significant except for the value of used equipment because the difference of the equipment value was very small for various production scales and the contribution of equipment value to the entire cost was small, $<10 \%$.

Table 1 shows that rice farming in tidal swampland typology was likely to obtain a greater profit than the rice farming in freshwater swampland. It could be seen from the positive dummy coefficient that was 0.7275 and significant at the level of one percent. 
Input Demand Function (Factor Share )

Input demand function, also called factor share, is defined as the contribution of an variable input to a profit. Mathematically the variable input demand function (factor share) as a contribution of variable input to profit could be derived from the CobbDouglas profit function (Yotopoulos and Nugent, 1976 and Sukartawi, 1990). Estimation of rice farming demand function in two land typologies in South Kalimantan are presented in Table 2.

Table 2. Estimation of rice farming demand function in swamp lands and tidal lands in South Kalimantan

\begin{tabular}{lcccccc}
\hline \multirow{2}{*}{ Variable } & \multicolumn{2}{c}{$\begin{array}{c}\text { Model I } \\
\text { (OLS) }\end{array}$} & \multicolumn{3}{c}{$\begin{array}{c}\text { Model II (SUR) } \\
\alpha_{j}^{*} \alpha_{j}^{*} \neq \alpha_{i}^{*}\end{array}$} & \multicolumn{2}{c}{$\begin{array}{c}\text { Model III (SUR) } \\
\alpha_{j}^{*}=\alpha_{i}^{*}\end{array}$} \\
\cline { 2 - 7 } & $\begin{array}{l}\text { Parameter } \\
\text { Estimate }\end{array}$ & $\operatorname{Pr}>|t|$ & $\begin{array}{c}\text { Parameter } \\
\text { Estimate }\end{array}$ & $\operatorname{Pr}>|t|$ & $\begin{array}{c}\text { Parameter } \\
\text { Estimate }\end{array}$ & $\operatorname{Pr}>|t|$ \\
\hline Seed & -1.38787 & $<.0001$ & -1.43741 & $<.0001$ & -1.31486 & $<.0001$ \\
Fertilizer & 2.36434 & 0.0084 & 0.713043 & 0.2866 & -0.83254 & 0.0134 \\
Pesticide & -1.17318 & $<.0001$ & -0.46933 & 0.0253 & -0.70904 & $<.0001$ \\
Labor & -2.52968 & 0.0053 & -0.79792 & 0.2025 & -0.93891 & 0.0025 \\
\hline
\end{tabular}

Source: Primary data processing (2016).

In general, the law of demand explains that the lower the price of an item, the more the demand for goods and conversely; the higher the price of an item, the less the demand for goods. In other words, the relationship between price and demand is inversely.

Table 2 shows that in model I and model II the input demands were influenced by the input price itself with a negative sign except the fertilizer demand, but in model III where the maximum profit was achieved all inputs were influenced by the price with a negative sign in accordance with the theory of demand.

In condition where the maximum profit was reached, the parameter value of seed price was $-1,314$ at $99 \%$ confidence level ( $p$ value $<0.0001)$ indicating that any increase in seed price by $10 \%$ caused a decline in seed demand by $13.13 \%$. Likewise, the parameters of fertilizer price, pesticide price and labor cost, respectively influenced the input demand itself with a confidence level of
$99 \%$ with the value of each parameter 0,833 ; -0.709 ; and -0.939 . It meant that any increase in fertilizer price by $10 \%$ caused a decline in demand for fertilizer by $8.33 \%$. The increase in pesticide price by $10 \%$ led to a decline in demand for pesticide by $7.09 \%$, and the increase of labor cost by $10 \%$ led to a decline in demand for labor by $9.393 \%$.

Based on the coefficient value could also be seen that the fertilizers inputs demand, pesticides and labor were inelastic to prices while seeds input were elastic to price.

\section{Condition of returns to scale of rice farming}

Condition of returns to scale of rice farming needs to be estimated as it is an important analytical tool for decision making whether the scale of a rice farming should be increased, maintained or reduced. The results of returns to scale testing based on the profit function are presented in Table 3.

Table 3. Testing of returns to scale in rice farming in swamp and tidal lands in South Kalimantan

\begin{tabular}{ccccc}
\hline Hypothesis & $\sum_{i=1}^{5} \beta_{i}^{*}$ & F Value & Probability & Decision \\
$\mathrm{H}_{0}: \sum_{i=1}^{m+1} \beta_{i}^{*}=1$ & & & & \\
$\mathrm{H}_{\mathrm{a}}: \sum_{i=1}^{m} \beta_{i}^{*} \neq 1$ & 0.6369 & 3.22 & 0.0138 & Decline Ho
\end{tabular}

Source: Primary Data Processing (2016) 
Based on the results of statistical test in Table 3, it appeared that the decision taken was to reject the null hypothesis, which meant that we rejected the hypothesis stating that the observed rice farming in condition of constant returns to scale.

Total regression coefficient of input $=$ 0.6369 which was less than one indicated that the condition of rice farming studied was on the condition of decreasing returns to scale. This fact showed that if all inputs were duplicated one time, it would increase the rice farming profit with a smaller proportion than one. In other words, the increase rate of all inputs was greater than the increase rate of profit level.

\section{CONCLUSIONS}

Rice production in the study area was significantly influenced by seed, fertilizer, and labor. The price of the production facilities in the research area was very influential on the profitability of rice farming, so the increase in price for production facilities would lead to a decrease in profit, which in turn would lower the level of farmers' welfare. This was reflected in the estimation of production factor prices, all of which negatively influenced the profit. Under the optimal condition (Model III) where the maximum profit was reached, the effects of variable input prices and the number of fixed inputs were significant except for the value of equipment used because the difference in the equipment value was very small for various production scales and the contribution of the equipment value to all necessary cost was small, $<10 \%$. Based on the value coefficients, the input demand function of fertilizer, pesticide and labor was inelastic to price while seed/seedling input was elastic to price. Rice farming in the research area had decreasing returns to scale. It indicated that the increase in inputs was higher than the increase in profit level, so when the farmers wanted to improve profits, the average cost would also increase with higher proportion.

Because the prices of production facilities in the study area is very influential on the profit of rice farming, the increase in production prices means that the prices will cause a decrease in profit. The government support for farmers is very essential, especially with regard to the provision of the production facilities, such as the subsidies for fertilizers and pesticides as well as the easiness in the provision of farm credit (KUT).

Considering that the profit level achieved by producers is determined not only by the production size but also by the input and output price, when the growing season has arrived, the government should take a controlling role for the smooth distribution of the production facilities, especially the availability of fertilizer and stability of other input prices.

Based on the conclusion that the rice farming in the study area was in the condition of decreasing returns to scale, the efforts to increase profit need to be carried out carefully because the average input cost will also increase higher than the profit.

\section{REFERENCES}

Alihamsyah, T. (2005). Development of Freshwater swampland for Farming. Swamp Land Agricultural Research Center. Agricultural Research and Development Agency. Banjarbaru.

Hanani, N. (2011). Strengthening Community's Social Economic Condition in Achieving Food Security. Proceedings of the National Seminar. Jambi University 19 February 2011.

Hanani, N. (2012). Strategy of Six Pillars for Food Security Development. Inauguration speech in Agricultural Economics at Faculty of Agriculture. Brawijaya University. Malang.

Hidayat, T. (2010). Science Contestation with Local Farmers' Knowledge in Tidal swampland Management in South Kalimantan. Dissertation. Postgraduate program. Bogor Agricultural University. Bogor.

Noor, M. (1996). Marginal Rice Land. Penebar Swadaya. Jakarta.

Noor, M. (2007). Freshwater Swamps: Ecology, Utilization and Development. Rajawali Press. Jakarta.

Nugroho, K., Alkasuma, Paidi, W., Wahdini, Abdulrachman, H., Suhardjo, \& Widjaja-Adhi, I.P.G. (1991). Final Report. Determining Potential Areas of Tidal Lands, Swamps, and Beaches. A scale of 1: 500,000. Technical report No. 1/PRSP/1991/. Research Project of Land 
Rifiana, Kamiliah Wilda, Yudi Ferrianta: Analysis Of Profit Function And Returns To

Resources. Soil and Agro-climatic Research Center.

Purwaningsih \& Yunastiti. 2008. Food Security: Situation, Problems, Policy and Community Empowerment. Development Economics Journal 9 (1): 1-27.

Ramonteu, S., Gutierrz, M.L. \& Levang, P. (2000). Between Land and Water. Ministry of Transmigration and Forest Squatter Resettlement. Jakarta.

Saliem, H. P., Lokollo, E.M., Purwantini, T.B., Ariani and Marisa, Y. (2005). Food Security Analysis of Household and Regional Levels. Agro Economic Bulletin.

Sarwani, M. (1994). Environmental Aspects in Tidal Land Development. A Case of Peat Region Depreciation in Peat Areas of Pulau Petak Delta in South and Central Kalimantan. Research Institute of Food Crops. Banjarbaru. 